\title{
SIMULATIVE RESEARCH IN A FINANCIAL INSTITUTION: IMPROVING SERVICE QUALITY IN LITHUANIAN BANKING SECTOR
}

\author{
Dainora Grundey
}

\begin{abstract}
Financial services institutions tend to provide comparable services at similar prices. The ability of organisations to gain competitive advantage by the use of product differentiation is limited, because financial service products can be copied within a relatively short space of time.

However, how the quality of client service could be assessed? Simulative assessment of client service quality has been initiated at the bank as a totally new method applied in the service sphere in our country. Meanwhile, other banks do not carry out such investigations, as they focus more on the analysis of client needs, their financial capacities, analysis of competitors, etc. The pending issues suggested researching the following tasks in this paper:

- Service quality management in financial institutions.

- Service quality: some implications for sales force in financial institutions.

- The training implications for a market-oriented financial company.

- Substantiation of the internal research of service quality at $A B$ bank HANSA-LTB, Lithuania with main findings and conclusions.
\end{abstract}

Keywords: financial institutions, service quality, sales force training, AB bankas “Hansabankas”, Lithuania. 